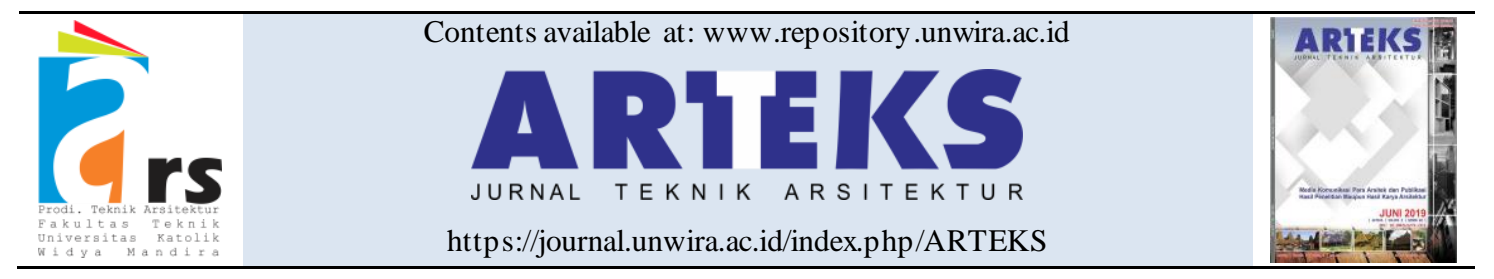

Research paper

doi: 10.30822/arteks.v6i1.286

\title{
The conception of actor network in Jelekong art and culture village of Bandung Regency
}

\author{
Eko Bagus Prasetyo*(1), Agus Suharjono Ekomadyo \\ Architecture Study Program, School of Architecture, Planning and Policy Development \\ Institut Teknologi Bandung, Jl. Ganesha no. 94, Bandung, Indonesia
}

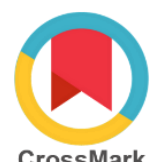

\begin{tabular}{|c|c|}
\hline ARTICLE INFO & ABSTRACT \\
\hline $\begin{array}{l}\text { Article history: } \\
\text { Received March } 01,2020 \\
\text { Received in revised form April } 01,2020 \\
\text { Accepted October } 11,2020 \\
\text { Available online April } 01,2021 \\
\end{array}$ & $\begin{array}{l}\text { Jelekong is an art and culture village in Baleendah Sub-district of } \\
\text { Bandung Regency which is well known for its activities in paintings } \\
\text { and wayang golek or puppet crafts. The village's character related } \\
\text { to art is also shaped by several actions and relationships between } \\
\text { socio-technical actors apart from the existence of artists and their }\end{array}$ \\
\hline $\begin{array}{l}\text { *Corresponding author: Eko Bagus } \\
\text { Prasetyo } \\
\text { Architecture Study Program, } \\
\text { School of Architecture, Planning and Policy } \\
\text { Development, Institut Teknologi Bandung, } \\
\text { Indonesia } \\
\text { Email: prasbagus81@gmail.com } \\
\text { ORCID: https://orcid.org/0000-0001-5353- } \\
\text { 0900 }\end{array}$ & $\begin{array}{l}\text { activities. This research was, therefore, conducted to describe } \\
\text { Jelekong Village as a heterogeneous socio-technical network by } \\
\text { identifying and analyzing several actors and actions using Actor- } \\
\text { Network Theory (ANT) which is a qualitative research method. Five } \\
\text { network-actor conception prepositions including 1) the will of actan, } \\
\text { 2) actors, 3) composition and translation of action, 4) network } \\
\text { locality, and 5) network representation were reviewed to determine } \\
\text { the phenomenon of the heterogeneous network formed in the village. } \\
\text { The results showed several factors required in becoming Jelekong } \\
\text { Village network and they include 1) the artist's will to initiate art } \\
\text { actions, 2) existence of sociotechnical agent such as actors and } \\
\text { resources related to the artist, 3) a very complex art relationship, 4) } \\
\text { establishment of an art environment such as a studio and gallery, } \\
\text { and 5) the meaning of art space for artists as a forum to preserve } \\
\text { arts and culture as well as potential economic resources. }\end{array}$ \\
\hline
\end{tabular}

\section{Introduction}

Indonesia is a country with varieties of rich regional arts, traditions, and cultures (IndoMaritim 2020). This is reflected in the existence of community environmental units collectively preserving and developing different arts and cultures such as the traditional, art, and urban villages widely used as themes or symbols of creativity (Wardhani et al. 2016). The art village is a settlement having the majority of its residents working as artists (Kurniawan 2007; Priyatmoko and Purwanto 2013). It is a place where artists live and produce artworks which are useful not only for art connoisseurs but also for the artists to actualize and fulfill their economic needs (I. Setiawan 2012; Purbadi and Lake 2019). Many art villages in Indonesia have been developed into tourist centers to empower arts and increase the welfare of the artists (Prasetyo et al. 2020).

One of these art and culture villages is Jelekong which is located in the Baleendah Subdistrict of Bandung Regency. This village is known for its wayang golek or puppet crafts, puppetry arts, and painting. The puppet crafts and puppetry arts were first pioneered in 1957 by puppeteer Abeng Sunarya while painting was first introduced in 1969 by artist Odin Rohidin (Darsiharjo and Galihkusumah 2014; N. A. 
Setiawan and U. 2014). Art activities in this village are passed down from one generation to another and, after the is suance of Bandung Regent Decree Number 556.42/Kep.71-Dispopar/2011 regarding the designation of Jelekong Village as a tourist village in Bandung Regency, the artists activated community-based tourism programs through art activities and performances (Sumantri 2019). This tradition of preserving arts and supporting touris $m$ activities strengthen the sense of place in Jelekong Village as an area with artculture characters.

The art and cultural characters of Jelekong Village as a residential unit were constructed through several agents, events, and relationships between social actors and technical objects. The art and culture village label is not only due to the presence of artists as social actors neither are the events limited to the creation of artworks using available tools and materials by the artists. Several other activities involving heterogeneous agents are also being used in maintaining the status of the village and these include building galleries and workshops, purchasing art tools and materials in shops, training students, art exhibitions and performances for visitors, selling artworks to distributors and connoisseurs, and organizing artist community events. These activities are, however, connected to each other and are affected by the composition and adjustment of several actions (Callon 1984; Lezaun 2017; Yuliar 2015). This, therefore, means it is more appropriate to refer Jelekong Village as a heterogeneous network instead of being called a single social structure.

This study was conducted to discuss the network-actor conception in Jelekong Art and Culture Village. This involved reviewing and identifying several actors and actions used in forming a heterogeneous socio-technicalnetwork unit for the "Jelekong Village". Moreover, ActorNetwork Theory (ANT) approach was used to analyze different social agents and material artifacts related to the artist as well as a series of initiations, compositions, and translation or adjustments of actions occurring between these heterogeneous artists and actors to produce stable socio-spatial associations. In the end, the results are expected to provide more insight into the phenomenon of socio-spatial associations in Jelekong Village using a "sociotechnical" framework.

\section{Method}

The Network-Actor Theory (ANT) approach was used to analyze and describe ideas on actions, hybrid agents, heterogeneous networks, and processes in maintaining network integrity in a sociotechnical entity. This theory states that an analysis starts from the network with the actors serving as a unit (Akrich and Latour 1992; Latour 1996; 2005; Law 2000). Networks are formed by different actors, including social agents and material artifacts, which conversely obtain their source from the network. ANT is usually used to review the real process of order in an uncertain connection motion to gradually become or in becoming without focusing on a pregiven structure in a fundamentally regular state (Couldry 2008).

The ANT approach was used to explain the network-actor conception in Jelekong Art and Culture Village is explained. Data were collected through direct observation in the field and interviews with local artists. The direct observations were used to retrieve primary data on physical entities related to the activities of the artists such as gallery room, workshop, or studio rooms as well as the art equipment and materials . Meanwhile, the interviews were used to obtain factual, distinctive, and multidimensional qualitative data through direct explanations from informants.

The data were used to review five prepositions of the actor-network concept which include: (1) the will of actan; (2) actors; (3) composition and translation of action; (4) network locality; and (5) network representation (Callon 1990; Latour 2005). Actor refers to all kinds of agents capable of performing certain actions in the network (Latour 1992) while actan is defined as the actors specifically playing a role in initiating and controlling the action. Meanwhile, the composition and translation of action refer to a series of processes used in arranging and adapting different actions in the network (Callon 1984). Network locality is also explained as the effect of framing and establishing the locus of relations in the network while network representation is related to the results of calculation-qualifications by actors on the existence of networks and other actors (A. S. Ekomadyo and Riyadi 2020; A. Ekomadyo and Yuliar 2015). The review of these five actor-network prepositions showed several sociotechnicalindicators in Jelekong Village such 
as the: (1) motivation of artists in pursuing art activities; (2) different actors and resources involved; (3) several relationships of art activities; (4) formation of the existing art environment; and (5) the meaning of space for the artist. These were further used to trace the phenomenon of becoming a heterogeneous network based on a series of processes used in composing and translating actions among the actors in the village.

\section{Result and discussion}

General description of Jelekong Village

Jelekong Village is located in Baleendah Subdistrict of Bandung Regency and bordered by Bojongsoang Village to the north, Wargamekar Village to the east, Patrols ari Village to the south, and Manggahang Village to the west. It is traversed by a Laswi-Ciparay Road and two main neighborhood roads which are Giriharja and Jelekong. The area along Giriharja Road is a center for wayang golek crafts while those crossed by Jelekong is a center for painting as indicated in figure 1 .

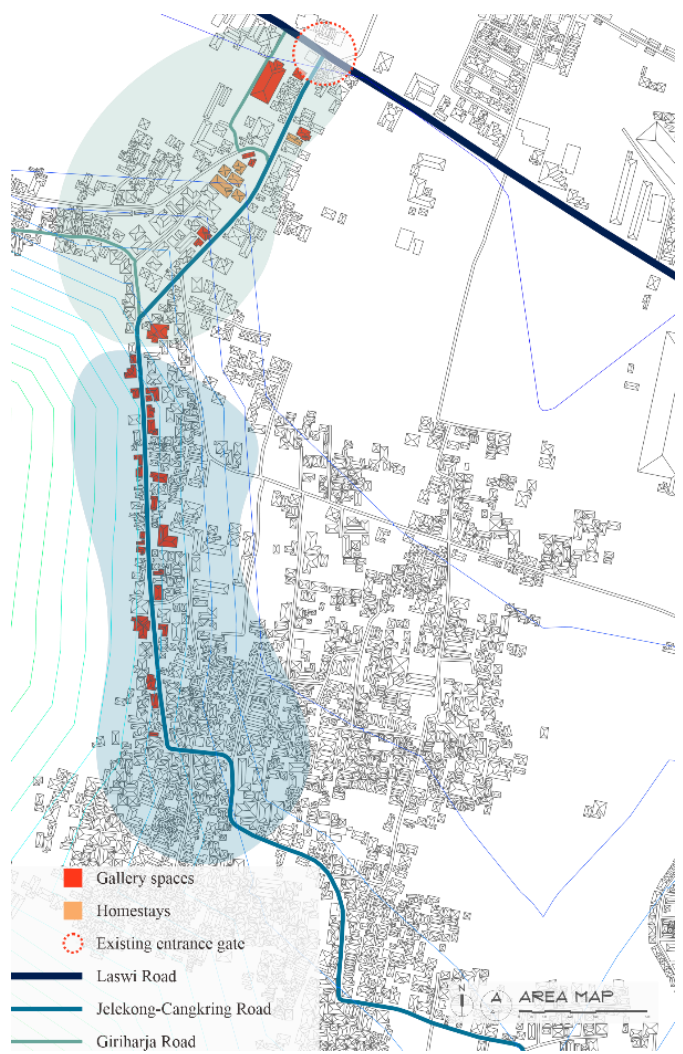

Figure 1. Jelekong Village map
Almost all art and culture spaces built such as galleries and workshops are lined up along the main neighborhood roads including the Giriharja and Jelekong. The gallery and studio spaces built were observed to have the same spatial design which involves utilizing the front of the residential house facing the street as an art display and performance rooms with a semi-open model as shown in figure 2. The interviews conducted showed this is a tactic deliberately used to ensure art production activities are placed in a more strategic location to be seen by many people. This means the choice of these locations is to attract visitors and increase the selling power of artworks to potential buyers.

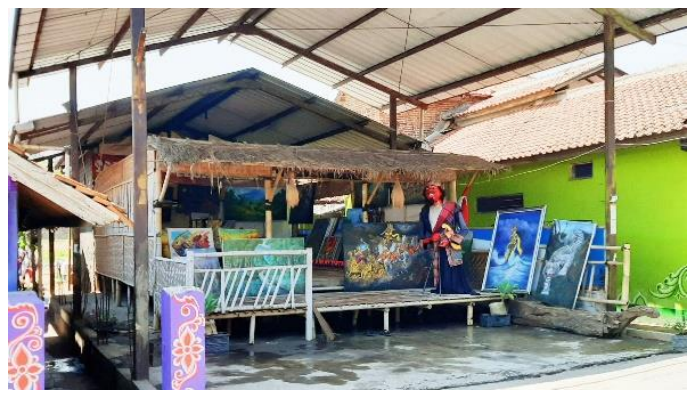

Figure 2. The character of a semi-open gallery

Art expertise has been passed down from one generation to another since the introduction of its activities by two prominent artists, Abeng Sunarya and Odin Rohidin. Unsurprisingly, even though environmental conditions have changed, the distinctive character of art inherent in the village is still strong and has been preserved up to the present time. The art talents possessed by each artist are used in sustaining daily livelihood while the activities previously used to express oneself and enjoy the spare time have been developed to satisfy household economic needs as shown in figure 3 . Therefore, the arts and culture activities in the village are closely related to the production and distribution of handicraft products as a commodity.

The works of the artists are used as commodities to attract the attention of art connoisseurs and collectors. These visiting connois seurs not only buy the work of local artists but also enjoy the tourism activities with their family or group in the form of direct observation of the art and culture process. This has gradually increased in the number of tourists in the village, especially during the holiday seas on. This tourism potential observed by the residents led to the 
development of tourist accommodation facilities such as homestays, performance rooms, dining places, and souvenir shops.

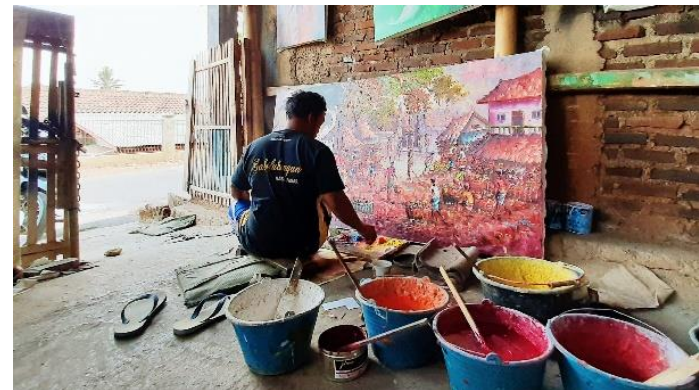

Figure 3. Art activities

Analys is of actor-network conception in Jelekong Village

The five prepositions of the actor-network concept reviewed mapped the sociotechnical indicators in Jelekong Village to include the 1) artist's motivation in the arts, 2) actors and resources involved, 3) art activities relation, 4) formation of an art environment, and 5) meaning of space for the artist.

\section{1) Artist motivation}

The artists basically acting as initiators and controllers of the action (actants) in Jelekong Village have motivations and goals before engaging in a series of actions and relationships with others. Every art activity voluntarily conducted by these artists is always encouraged and driven by will or desire and, in Jelekong Village, this is generally associated with the continuation and preservation of art traditions passed down from previous generations and which has become a common value. However, this is not the sole objective and this means there is a need for the people to preserve art activities and als o become an artist. This is evident from the existence of other desires motivating artists to perform certain actions such as interests and hobbies, desire to express themselves, and pursuing livelihood opportunities in the arts in addition to the encouragement to preserve environmental art traditions.

\section{2) Actor and art resources}

Some other individuals involved in art activities in Jelekong Village are actors establishing actions and relationships with artists, resources, and art products as well as different mediums mobilized by artists to maintain these actions and relationships as described in figure 4 . Some of the actors observed to be exploring these actions include family and relatives, art connoisseurs, buyers and distributor agents, suppliers of craft tools and materials, tourists, art connoisseurs, exhibition organizers, goods delivery agents, a community of artists, students, researchers, servants' workers, and owners of rented houses. Furthermore, the material artifacts involved in circulating actions concerning the will and competence of artists include the delegated resources such as tools and materials, venture capital, gallery and workshop space, rented houses, marketing systems, communication tools, and the internet. Other important liais on actors to continue the artists' actions and also to develop and re-stabilize the social-spatial network in the village include the art products in the form of paintings and puppet shows, inherited skills, and profit from sales.

The material artifacts in the socio-spatial network of the village play an equally important role as the social agents implementing the action with the artists. The stability of the network is disrupted without their presence, for example, it is impossible to run art activities without sufficient business capital, scarcity of paint materials also hinder the process of making paintings, absence of workshop space makes it difficult for artists to produce their best works of art, and good galleries space ensures smooth transactions between artists and buyers. This means the lack of one or more of these elements creates an unstable network situation with the artists experiencing problems in linking resources, producing, and maintaining important relationships with their partner actors. This explanation concludes that the absence of certain material artifacts has made it difficult to stabilize and re-explore actions among artists, social agents, and other material artifacts. 


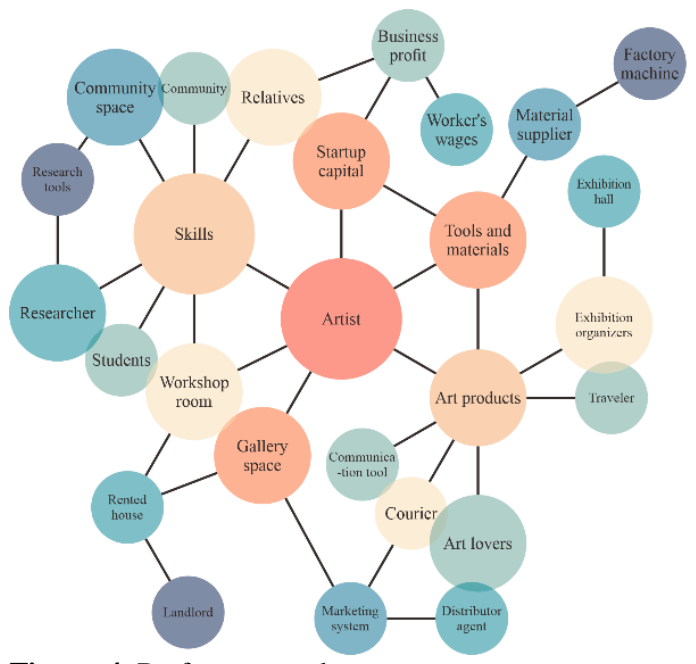

Figure 4. Performers and art resources

3) Art activity relations

The observation of the art activities in Jelekong Village showed several actors are involved in the manifestation of actions and relationships with artists. The process is actually a collection or composition of several actions by these artists and several other actors as shown in figure 5 rather than through single action. The activities are not limited to the preparation of materials and tools in the workspace but also as sociated with the creation of works of art which are offered to art enthusiasts. This means artists need to buy craft tools and materials from suppliers and also arrange a comfortable workshop space to work in creating artworks. Some were discovered to have rented a house which is used as the works pace and also to store their products. Furthermore, activities after the art creation process include displaying in the gallery space, selling directly to buyers, entrusting artworks to distributing agents, and providing wages to workers. Subsequently, other activities related to art action include organizing exhibitions and performances, conducting training for the younger generation and students, creating a sales system through online media, participating in community events, and providing accommodation for tourists.

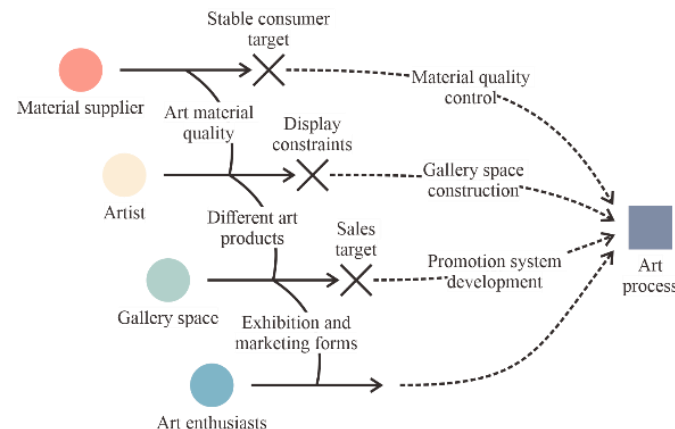

Figure 5. Translation of art action

This composition allows artists and other actors to delegate, establish relationships, mediate, translate, and limit actions to ensure a smooth-running process according to goals. A change in one of the actions changes the whole chain and causes network instability. For example, the inability of a supplier to provide enough craft materials for artis ts due to scarcity of resources means a smaller amount of artwork is produced, thereby, leading to reduced income and limited capital to buy craft tools and materials at a later time. This, therefore, shows there is a very complex relationship socio-spatial network between actors in Jelekong. This was, however, arranged quite neatly and localized or isolated at a certain time due to the sophistication of the as sociation process obtained fromthe competence and translation of the actors. This further led to the formation of a kind of frame which covers the complexity of the heterogeneous network and reflects a simplicity effect when viewed from the outside. This indicates the socio-spatial network in Jelekong Village is only seen as an active relationship between the artist and the physical space unless further investigation is conducted.

4) The formation of the art circle

The locality of the network in Jelekong Village is reflected in several art circles formed. The art environment has become a form of tissue locus which is easily physically observed and causes art associations to appear in a simpler relationship limited to the artists and primary resources mobilized as indicated in figure 6. This means the art activities in the village only has the ability to produce artistic goods in a stable condition. 


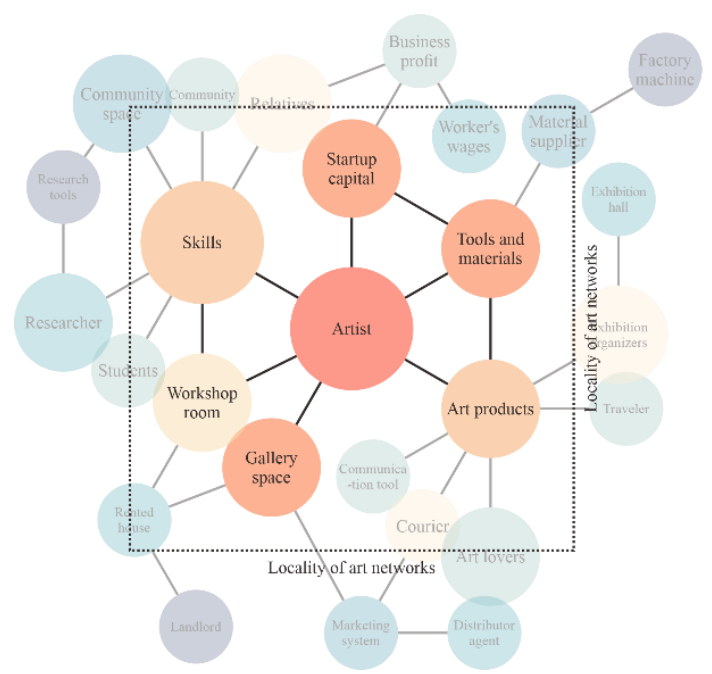

Figure 6. Locality of art networks

Art circles were established for symbolic purposes which include distinguishing art characters and providing identity to each artist. The formation of an art environment in Kampung Jelekong is represented by the construction of a studio, gallery, and hermitage with a specific name, vision, and organizational system. Each of these galleries and hermitage is built to accommodate groups of artists which are relatives and close relatives with the same form, genre, ideology, and art goals. Moreover, the centering of the wayang golek craft environment in the Giri Harja area and painting in the Jelekong area has also become a more macro entity with the network locality, in the form of the art environment, causing branching of several loci. However, this phenomenon strengthens the internal relations of the actors involved, facilitates relations between the network focus, and maintains the network as a whole.

5) Meaning of space for artists

The network locality had the effect of "simplifying" the complex heterogeneous network in Jelekong Village due to its ability to divide a complex network into several loci containing internal entities and more specific "systems". This simplifying effect allows even very complex heterogeneous networks to behave like a "black box" which is a device characterized by its stable and regular behavior. Therefore, the socio-spatial network is projected to be seen as a unity of action and intensive relations between the artists and their physical spaces including the studios and galleries. This further means the network representation in Jelekong Village is seen and identified from the meaning of the existence of art spaces such as studios, galleries, and art hermitage for practical research purposes. The network is generally represented by art gallery spaces as a forum to preserve arts and culture, ensure economic potential, and to develop objects of community-based tourism. It is impossible to separate the meaning of space for an artist from the influence of the artist's will, other actors as well as the series of actions involved. Furthermore, the existence and meaning of space discovered by ANT for these artists are traced back to several other spatial formations such as local houses, neighborhood roads, art raw material factories, and tourist accommodation spaces and their meanings for the actors involved with the artists.

\section{Conclusion}

It is more appropriate to define Jelekong Village as a heterogeneous network than to call it a single social association and this means its existence is not only formed by the presence of human agents and social activities. The village is well known for its art and culture characters constructed by hybrid actors including social agents and material artifacts which explore and translate collective action through a series of sociotechnical relations. It is formed by the continuous and repeated composition and translation activities between relational factors to maintain the stability of its heterogeneous network. Furthermore, this status was discovered to be a continual phenomenon and not a regular pregiven structure from the start.

Several things were found in the process of attaining this network status. First, the artists had several tactical intentions to initiate art actions. Second, several actors and resources are related to the artist. Third, there is a very complex relationship between the artist and the other actors involved. Fourth, art circles are formed because the art associations appear simpler despite the complexities. Fifth, the art spaces are primarily interpreted by the artists as a forum for art-culture development and a way to improve the economy. Finally, the existence of other spatial formations such as houses for residents and tourist accommodation spaces, and the meanings the present to the actors involved with the artis ts were determined based on space existence and 
meaning. These results are expected to provide an overview of Jelekong Art and Culture Village as a more comprehensive form of the socio-spatial association from a sociotechnical pers pective.

\section{References}

Akrich, Madeleine, and Bruno Latour. 1992. 'A Summary of a Convenient Vocabulary for the Semiotics of Human and Nonhuman Assemblies'. In Shaping Technology/Building Society Studies in Sociotecnical Change, edited by W. E. Bijker and J. Law, 259-64. London: MIT Press Cambridge.

Callon, Michel. 1984. 'Some Elements of a Sociology of Translation: Domestication of the Scallops and the Fishermen of St Brieuc Bay'. The Sociological Review 32 (1_suppl): 196-233. https://doi.org/10.1111/j.1467954X.1984.tb00113.x.

. 1990. 'Techno-Economic Networks and Irreversibility'. The Sociological Review 38 (1_suppl): 132-61. https://doi.org/10.1111/j.1467954X.1990.tb03351.x.

Couldry, Nick. 2008. 'Actor Network Theory and Media: Do They Connect and On What Terms?' In Connectivity, Networks and Flows: Conceptualizing Contemporary Communications, edited by A Hepp, F. Krotz, S. Moores, and C. Winter, 93-110. Cresskil, NJ, USA: Hampton Press, Inc. https://core.ac.uk/download/pdf/16380981.pd f.

Darsiharjo, and Ahmad Hudaiby Galihkusumah. 2014. 'Analisis Rantai Nilai Industri Kreatif Di Desa Wisata Jelekong Kabupaten Bandung'. Jurnal Manajemen Resort \& Leisure $11 \quad$ (1): 35-41. https://doi.org/10.17509/jurel.v11i1.2900.

Ekomadyo, Agus S., and Andhika Riyadi. 2020. 'Design in Socio-Technical Perspective: An Actor-Network Theory Reflection on Community Project "Kampung Kreatif" in Bandung'. Archives of Design Research 33 (2): 19-37. https://doi.org/10.15187/adr.2020.05.33.2.19.

Ekomadyo, Agus, and Sonny Yuliar. 2015. 'Social Reassembling as Design Strategies'. Procedia - Social and Behavioral Sciences
184

(May):

$152-60$.

https://doi.org/10.1016/j.sbspro.2015.05.075.

IndoMaritim. 2020. 'Keragaman Budaya Daerah Adalah Kekayaan Budaya Nasional'. IndoMaritim.Id. 2020. https://indomaritim.id/keragaman-budayadaerah-adalah-kekayaan-budaya-nasional/.

Kurniawan, I Made. 2007. 'Kampung Seni: Tema Metafora Tari Dalam Arsitektur'. Institut Teknologi Sepuluh Nopember Surabaya. https://docplayer.info/65233769-Judul-tugasakhir-kampung-seni-tema-metafora-taridalam-arsitektur.html.

Latour, Bruno. 1992. 'Where Are the Missing Masses? The Sociology of a Few Mundane Artifacts'. In Shaping Technology/Building Society: Studies in Sociotechnical Change, edited by W. E. Bijker and John Law, 151-80. London: MIT Press Cambridge. https://www.open.edu/openlearn/ocw/pluginf ile.php/877054/mod_resource/content/3/dd30 8_1_missing_masses.pdf.

. 1996. 'On Actor-Network Theory: A Few Clarifications'. Soziale Welt 47 (4): 36981. https://www.jstor.org/stable/40878163?seq=1 . - 2005. Reassembling the Social: An Introduction to Actor-Network Theory. Newy York: Oxford University Press. https ://www.ufrgs.br/ppgas/portal/arquivos/o rientacoes/LATOUR_Bruno._2012.pdf.

Law, John. 2000. 'Notes on the Theory of the Actor Network: Ordering, Strategy and Heterogeneity'. In Organizational Studies: Critical Perspectives on Business and Management, 2nd ed., 853-68. London: Routledge.

https://www.lancaster.ac.uk/fass/resources/so ciology-online-papers/papers/law-notes-onant.pdf.

Lezaun, Javier. 2017. 'Actor-Network Theory'. In Social Theory Now, edited by C. Benzecry, M. Krause, and I. Reed, 1-36. Chicago: The University of Chicago Press. https://www.academia.edu/34100806/Actor_ Network_Theory_Social_Theory_Now_.

Prasetyo, Eko Bagus, Andrew Cokro Putra, Bima Rahmaputra, and Agus Suharjono Ekomadyo. 2020. 'Architectural Adaptation Strategy of Shophouses in Jalan Tubagus Ismail, Bandung'. ARTEKS : Jurnal Teknik Arsitektur 
$5 \quad$ (1): $\quad 1-10$. https://doi.org/10.30822/arteks.v5i1.72.

Priyatmoko, Heri, and Bambang Purwanto. 2013. 'Sejarah Sosial Komunitas Seniman Di Kemlayan Surakarta 1930-an-1970-An'. Universitas Gadjah Mada. http://etd.repository.ugm.ac.id/penelitian/deta il/62871.

Purbadi, Yohanes Djarot, and Reginaldo Christophori Lake. 2019. 'Konsep KampungWisata Sejahtera, Kreatif, Cerdas Dan Lestari Berkelanjutan'. EMARA: Indonesian Journal of Architecture 5 (1): 12-23. https://doi.org/10.29080/eija.v5i1.641.

Setiawan, Irvan. 2012. 'Keberadaan Kampung Seni Jelekong Dalam Menunjang Kebutuhan Ekonomi Rumah Tangga'. Patanjala : Jurnal Penelitian Sejarah Dan Budaya 4 (2): 58-73. https://doi.org/10.30959/patanjala.v4i2.140.

Setiawan, Nisa Amalina, and Farid Hamid U. 2014. 'Strategi Promosi Dalam Pengembangan Pariwisata Lokal Di Desa Wisata Jelekong'. TRIKONOMIKA 13 (2): 184-94. https://doi.org/10.23969/trikonomika.v 13i2.6 13.

Sumantri, Diaz. 2019. 'Strategi Pengembangan Desa Wisata Di Kelurahan Jelekong, Kabupaten Bandung'. Jurnal Geografi Lingkungan Tropik 2 (2). https://doi.org/10.7454/jglitrop.v2i2.47.

Wardhani, Saraswati T., Steafni N. Sabatini, Rachmaniatus D., and Tamiya M. S. Kasman. 2016. 'Identifikasi Kampung Kreatif Sebagai Strategi Kota Tangguh'. In Temu Ilmiah IPLBI 2016: INFRASTRUKTUR WILAYAH KOTA, edited by Gatot Adi Susilo, Putri Herlia Pramitasari, Ghoustanjiwani Adi Putra, Bayu Teguh Ujianto, and Hamka, 15-20. Malang: Fakultas Teknik Sipil dan Perencanaan Institut Teknologi Nasional, Malang. https://temuilmiah.iplbi.or.id/wp content/uploads/2016/12/IPLBI2016-B-015020-Identifikasi-Kampung-Kreatif-sebagaiStrategi-Kota-Tangguh.pdf.

Yuliar, Sonny. 2015. Tata Kelola Teknologi: Perspektif Teori Jaringan-Aktor. 2nd ed. Bandung: ITB Press. 